\title{
Perceptions of care among elderly couples
}

\author{
Eloise Panagio Silva' ${ }^{\mathbb{D}}$ \\ lara Sescon Nogueira ${ }^{2}$ (D) \\ Célia Maria Gomes Labegalini² ${ }^{\mathbb{D}}$ \\ Ligia Carreira² ${ }^{2}$ \\ Vanessa Denardi Antoniassi Baldissera² (D)
}

\section{Abstract}

Objective: To analyze the perceptions of care among elderly couples. Method: A qualitative exploratory-descriptive type study was carried out in Maringá in the state of Paraná, from May to June 2017. Data were collected through a semi-structured interview conducted at the home of 15 elderly couples and analyzed through Bardin's Content Analysis, discussed in the light of Jean Watson's Theory of Transpersonal Care. Results: Three thematic categories emerged: 1) meaning attributed to mutual care; 2) daily activities as forms of care and 3) feelings that permeate care among elderly couples. Conclusion: Elderly couples have multifaceted perceptions of care, permeated by their emotional relationship, bonding, partnership and everyday activities. Health professionals should consider the elderly couple rather than isolated individuals, in order to understand the multiple dimensions of care among elderly couples and their influences on health and well-being, facilitating integral and better quality care for this specific population.
Keywords: Health of the Elderly; Primary Health Care; Nursing; Nursing Care.

\footnotetext{
Universidade Estadual de Maringá, Departamento de Enfermagem, Graduação em Enfermagem. Maringá, Paraná, Brasil.

2 Universidade Estadual de Maringá, Centro de Ciências da Saúde, Programa de Pós-graduação em Enfermagem. Maringá, Paraná, Brasil.

Funding: Fundação Araucária. Programa Institucional de Bolsas de Iniciação Científica (PIBIC). Universidade Estadual de Maringá (UEM). 2016/2017. Edital 001/2016-PPG-PES.
} 


\section{INTRODUCTION}

Population aging demands a health care system organized with the elderly in mind ${ }^{1,2}$. In recent decades, health professionals, especially those in nursing, have become aware of the importance of elderly care. For this reason, a growth in geronticgeriatric nursing has been observed, which has allowed the training of professionals to create a type of health care focused on the expectations and needs of those aged over $60^{2}$ and based on an expanded perspective of care.

Health care for the elderly should consider the particularities of this population, as well as their physical, psychic and social aspects and issues related to the promotion of health, so that the care provided is adequate, resolutive and integral ${ }^{3}$. To this end, caring for the elderly should not only guarantee longevity but also quality of life, satisfaction and happiness ${ }^{3}$ - which includes understanding the importance of the fullness of conjugal life, encouraging the protagonism, autonomy and independence of elderly couples.

The relationships of elderly couples can frequently last for years, beginning in youth and surviving all the transformations of life until old age ${ }^{4}$. With children leaving home, physiological and emotional changes and in some cases the onset of illnesses, elderly couples begin to care for each other.

In this sense, understanding the perception of care among elderly couples is an important element of combining the care between the couple and the health practices aimed at this population, in order to provide quality health care $^{5}$, respecting transpersonality, autonomy and conjugality. Based on the foregoing, the thematic delineation of present study was the expression of care among elderly couples, outlined in the following research question: How do elderly couples perceive and experience mutual care? The study therefore sought to analyze the perceptions of care among elderly couples.

\section{METHOD}

A study with a qualitative exploratory-descriptive approach was carried out in a municipal region located in the north-central region of the state of Paraná, Brazil.

The target audience of the study was composed of elderly people living in an area covered by a Basic Health Unit (BHU) located in the municipal region and attended by the university extension project entitled "Home Nursing Care for Families of Elderly Care Dependents" (ADEFI) linked to the Nursing Department of the Universidade Estadual de Maringá.

The inclusion criteria for participation in the study were: being elderly, having a marital relationship with another elderly person, regardless of civil status, and living in the same household or maintaining daily coexistence with a partner/spouse. The exclusion criteria were that one of the partners/spouses lacked effective verbal or cognitive communication skills, according to information from the health team. A total of 15 elderly couples met the criteria and participated in the study.

Data collection took place during the months of May and June 2017, through a semi-structured interview, carried out at the home of the elderly. Two researchers participated in the interviews. The elderly couples chose to be interviewed together, without interfering in the discourse of their partners. A script prepared by three researchers was used as a tool. This was divided into two parts. The first was aimed at collecting data on the sociodemographic characterization of the study participants, and the other comprised the following open questions: What does to care for and be cared for mean to you? Do you think you take care of your partner? What kind of activities/actions reflect this care? Do you think that you are cared for by your partner? What kind of activities/actions reflect this care? What do you think of your married life? Do you believe that caring for and being cared for influences married life? Do you believe that your spouse influences your health? Why?

For the organization, treatment and analysis of the data, the interviews were audio recorded (with an average duration of 20 minutes) using a cell phone, then transcribed in full by the researchers, respecting the reliability of the discourse, and analyzed through thematic type Content Analysis, according to the assumptions of Bardin ${ }^{6}$. 
This analysis was carried out in five stages: preanalysis; exploration of the material; processing of data, with systematic organization into thematic units; and construction of inferences and interpretation of significant categories. The thematic analysis, as proposed by this technique, consisted of discovering the nuclei of meaning contained in the communications and the presence or frequency of appearance of which could indicate meanings for the chosen analytic object - mutual care - based on the theoretical referential ${ }^{6}$ of Transpersonal Care Theory.

The categories that emerged from this analytical process were discussed in the light of Jean Watson's Theory of Transpersonal Care. This theoreticalphilosophical referential portrays care as the basis of Nursing practice and science, focusing on human relations and spirituality as essential to care and healing, as well as the intersubjectivity that make up caregiving ${ }^{7}$. Considering care as an inter-relational and social construction, which must be permeated by a bond and sensitivity, this framework was used to support the present study, as care for elderly couples is a phenomenon that can impact their health and care practices.

All the ethical and legal precepts of National Health Council Resolution No 466/2012 were met $^{8}$. The participants signed two copies of a Free and Informed Consent Form, one of which they kept. To ensure anonymity, the reports were identified with the letter "P", referring to the term "Participant", followed by Arabic numerals that corresponded to the order of transcription of the interviews. The study followed all the guidelines of the Consolidated Criteria for Reporting Qualitative Research (COREQ) for qualitative studies.

The research is part of a more comprehensive study and was submitted for the ethical appreciation of the Standing Committee on Ethics in Research with Human Beings (COPEP) of the Universidade Estadual de Maringá, and was approved under $\mathrm{N}^{\circ}$ 1.954.350/2017.

\section{RESULTS AND DISCUSSION}

Fifteen elderly couples were interviewed, giving a total of 30 participants, of whom 15 were men and
15 were women. Ages ranged from 60 to 82 years (mean of 66.4 years). The majority of the elderly $(n=18)$ had an incomplete elementary education, while three had completed elementary school, two had an incomplete high school education, one had completed high school, one had an incomplete higher education and five were illiterate.

In terms of occupation, 27 elderly people said they did not work and 19 were retired. The average time spent living with a current partner was 46.8 years, with the shortest period two years and the longest 61 years. Number of children ranged from zero to 11 (mean of 8.9 children), while number of grandchildren ranged from zero to 23 (mean of 16.7). Only four couples had great-grandchildren, with numbers ranging from one to six and an average of 2.6.

Care is part of the human condition and is a way of expressing humanity. Its definition is complex, as it is a multifaceted and constantly evolving concept ${ }^{7}$. In this way, it can be expressed in different ways. In this study, it was organized through three thematic categories that emerged from the data analysis: 1) the meaning attributed to mutual care; 2) activities of daily living as forms of care and 3) feelings that permeate care among elderly couples.

\section{1) The meaning attributed to mutual care}

For the elderly participants in the study, care contributes to well-being and enables the promotion of health. In this way, the elderly feel cared for when they face an illness and also when their partner helps with their recovery, as the following statements show:

"Caring is to care for her when she is sick, to heal, to medicate, to feel the pain she is feeling. Wanting her to live [...] This is the feeling I have for her, and for me care is contained there". (P2)

"I think this care [between the couple] is good for the health, because I feel good when I am cared for". (P15)

"I think that his care has a positive influence on my health and my life, because we have to go through a lot of things in life, and if we just fight all the time, it doesn't work". (P6) 
"Have you ever thought you were alone and sick, with no one to share your pain? Caring for one another helps a lot". (P9)

"Sometimes we forget to take care of ourselves and end up failing. It is a way of prolonging life, God willing, taking care of each other, we last longer. Care is a privilege for those who have it". (P30)

Care among elderly couples in times of frailty is shown as a way of demonstrating affection, concern and also reciprocating the care and attention one has received from a partner who is now ill. Yet, care can also convey trust and empathy, increasing affective bonds, promoting much more than simple tasks of helping the patient, building a bond wrapped in feelings such as empathy, protection, attention, readiness and understanding ${ }^{4,5}$.

It therefore creates a perception of love, care and patience for the caregiver, and a way of demonstrating protection, care and affection for those receiving care $^{4,5}$. These displays of affection involving care between couples can strengthen the relationship, improve the sense of well-being and quality of life of both, and consequently promote health ${ }^{10}$.

During times of illness, transpersonal care among elderly couples manifested itself in being together, in reciprocity and in loving, establishing conditions necessary for rehabilitation and healing? The home as an environment of support and protection, expressed by the posture of one's spouse, can help an individual cope with the common disorders of aging and pathologies, preserving physical and cognitive status?

In this context, care between a couple in times of disability also reinforces the overall functionality of the elderly person, which is the ability to manage and care for one's own life. This is closely related to well-being, as it generates independence (the ability to accomplish something through one's own means) and autonomy (decision-making capacity) ${ }^{11}$.

Although not frequently mentioned, the faith and spiritual support revealed in the discourse of one of the elderly individuals can provide benefits for care during situations of uncertainty and illness, bringing comfort and allowing elderly couples to experience unconditional support. Thus, manifestations of care permeate the beliefs of individuals and are essential elements of transpersonal care, and should be explored by health professionals as a therapeutic strategy?

In addition to the bond and affection shown by the elderly towards a spouse when they are frail, there is also a sense of reciprocity, in which an elderly person cares for their partner as a form of repaying care they once received or will yet receive, as the following reports show:

"It's like that here, when she needs something, I do it. When I need it too, she does it for me. If we're together it's to take care of each other". (P4)

"Yes, we care because we're together, don't we? I had eye surgery and he took care of me and the house". (P23)

"I think that when you care for someone he reciprocates by caring for you. You care and you're cared for". (P9)

Everyone needs to be cared for at some point in their life, while at other times they provide care, especially when involved in a relationship and during the aging process. The development of the elderly persons, constructed through family values and personal experiences, emphasizes care as a form of repayment and duty towards the other. This concept is constructed through beliefs, principles and values acquired during life, and can also involve other structural aspects such as affection, love and attention ${ }^{7,10}$ that permeate the life of a couple, according to the elderly persons.

In this sense, the concept of the reciprocity of care was clear, as the elderly described performing mutual care, which allows spouses to support the biopsychosocial and spiritual needs of their partners, valuing the interpersonal relationship, which involves transpersonal care ${ }^{7}$.

\section{2) Activities of daily living as forms of care}

The performance of household activities such as cleaning the house, preparing food, taking care of clothes and other things that keep the home clean, 
pleasant and comfortable was also an expression of care, as identified in the following statements:

\footnotetext{
"He takes care of me [...] he sweeps the yard even though I tell him that the leaves fall all the time, so there is no need to keep sweeping all the time [...] I think these things are a way of taking care of me ". (P6)
}

"She takes care of me because she makes lunch, makes dinner, makes food, washes clothes, cleans the house ... so she's taking care of me". (P11)

"I take good care of things, I always leave the clothes neat, food ready, the house is always clean". (P17)

"If I'm doing something and he's got nothing to do, he helps me do it.” (P19)

Caring is expressed in different ways and aimed at meeting the needs of the other. In the present study care in the home represented help and partnership, as well as caring and concern, seeking to provide one's partner with an environment that goes beyond their basic needs, and is comfortable and welcoming ${ }^{7}$. In this way, domestic tasks allowed an understanding of the care between elderly couples in a genuine manner, performed for the other, in a transpersonal manner, with love, empathy, concern and attention?

Domestic chores are demonstrations of care as they involve dedication, time and energy, especially when exercised by elderly men, who break gender stereotypes for the sake of their partner ${ }^{12}$. The fact that elderly men courageously break this tradition of the domestic responsibility of the woman - and see these tasks as a marital duty, shows reciprocity towards their wives and gratitude for the care they receive on a daily basis.

The day-to-day relationship and domestic demands emerged as a demonstration of care for the elderly in the present study. Care is not provided alone, as individuals need another to care for and be cared for, and this action pervades the relationship as a whole, not only with one's spouse, but also with the other members of one's family, home and social elements? ' Therefore, it is very important that these attitudes are stimulated and encouraged, through examples of caring for the male population, and of elderly men caring for their wives, transforming social and cultural values ${ }^{12,13}$.

It was observed in the present study that men were involved in domestic activities in two ways: as support for their wives at times of need, with chores remaining her responsibility; and in an egalitarian manner, in which both have the same levels of responsibility. The latter, however, occurs more often in younger than elderly couples ${ }^{13}$.

The domestic tasks performed by the elderly help to maintain their overall functionality, as they are fundamental for the self-preservation and survival of the individual. These tasks are part of what are called Instrumental Activities of Daily Living (IADL), which indicate the ability of the elderly person to live alone in the community, and include activities of in-home and domestic care ${ }^{14,15}$.

These stimulate cognition (the ability to understand and solve daily problems), mood (motivation to perform activities) and mobility (the ability to move and manipulate), which are the main functional systems in the evaluation of the functionality of the elderly, and are able to provide more autonomy at the same time $e^{14}$.

\section{3) Feelings that permeate care among elderly couples}

Feelings that permeate care among the elderly couples were noted, and ranged from demonstrations of warmth and affection to mutual concerns and advice, highlighted in the following extracts:

"She always took care of me right, she has a lot of affection for me as I have for her. My wife to me is like a drop of water, delicate, she is a crystal and I have to take care of her". (P11)

“We've been married for many years. I think the affection and care I have for him is a good example for our children. I feel good doing it, I like taking care of him, I forget about myself to take care of him with pleasure”. (P12)

"The husband has to care for his wife as though she is his child. I have to take care of her and keep her from falling into a hole or tripping, taking care so that she does not cut herself'. (P2) 
"[...] If you suddenly need advice, or a warning: don't do this, or don't do that, or even exchange ideas, and so on. It's a type of care she has for me". (P26)

In the present study, long-term married life was closely related to the feelings that permeate the transpersonal care between the couples, such as: companionship, affection, demonstrations of security, reciprocity, friendship, love and mutual giving. In this sense, the transpersonal care that permeates the elderly couple is also related to the emotional capacity ${ }^{7}$ of the spouses.

In relation to health, it is emphasized that feelings alter thoughts, behaviors and life habits, and it is necessary to understand the same in the process of care $^{10}$. Positive feelings between couples were created through the interactions between partners and the establishing of a relationship of support and trust, constructed in the communication between the couples and in harmony, empathy, affection, honesty and the positive acceptance of the other, consistent with the interactionist assumptions of Watson?

Negative feelings about care among elderly couples were not captured in the present study and this may be related to transpersonal care, which according to Watson ${ }^{7}$ goes beyond the ego itself, contributing to care for the other. In this sense, showing sensitivity to a spouse's feelings, as evidenced in the discourse above, integrated the elderly persons with care as a human and transpersonal process ${ }^{7}$.

In turn, positive and harmonious relationships between elderly couples helped to maintain the autonomy of the elderly individual, and were related to the main functional systems of mood and communication, in other words the capacity to maintain positive relationships with one's environment, expressing feelings, wishes and ideas ${ }^{16}$.

Over the years life undergoes several changes, including children leaving home, which alters the family structure. In this context, elderly couples once again live as they did at the start of married life, only for each other. In these moments, care becomes essential in daily life, so that the relationship is strengthened, as shown in the following extracts:

\begin{abstract}
"We become more of a partner for each other, we take care of each other, sometimes we go out together, to the shop. We do everything together, after my girls got married it was just the two of us, we have to help each other". (P17)
\end{abstract}

"I'm content, we spend the whole day together and I feel really happy with her." (P11)

"After the children left home we became more attached to each other, because we each take care of the other". (P17)

The elderly couples described the experience of being cared for by their spouses as important and of great benefit to their well-being?. The family is of great importance to biopsychosocial well-being as it is an institution of support capable of modulating the functioning of the elderly, and can contribute to both their growth and their decline. Its absence can result in a greater risk of the loss of autonomy and independence, thus making family disability one of the great geriatric syndromes ${ }^{17}$.

Returning to the conjugal dyad, as explained in the discourse of the elderly, passes through a reorganization of the roles of both spouses, as they no longer have to provide their attention and concern to their children, but to each other, marked by a return to intimacy and long coexistence, as at the start of married life. In this phase, it is possible for couples to construct a greater, more affectionate bond, provided that within the relationship there is mutual help and companionship 4 .

Conversely, there are also cases where both individuals become distant due to difficulties in adapting to the new, two person lifestyle. This is related to the trajectory of their lives to date and the type of relationship they have constructed over the years. However, in most cases the response to these phases is positive and couples are strengthened by the union, affection and pleasure in cohabitation permeated by care $^{4}$, as was observed in the present study.

The acceptance of positive and negative experiences and feelings during the events of life alter the thoughts and behavior of the elderly and can interfere with their physical and psychological health. In this way, their feelings and life histories 
need to be considered in the relationship of care, either between the couples or with health teams?.

Given the above, care should go beyond the management of the diseased organ or biological or physiological disorders, and should include the holistic dimension of care, involving spirituality, beliefs, values, psychological changes and social needs ${ }^{7}$, which are pertinent to overall functioning ${ }^{14}$. To achieve this and when seeking integral care, health professionals must offer receptive, qualified listening and care for couples, and not just individuals, offering support even in conjugal relationships.

Transpersonal care focuses on the individual as multi-faceted beings. From this perspective, care actions should integrate all the dimensions involved in human beings ${ }^{7}$ avoiding the common reductionism of care to biological aspects that involve the disabilities, frailties and physical difficulties affected by aging. The elderly couples in the present study recognized human complexity, and expressed it through extended day-to-day care.

The limitations of the present study are related to the data collection process, as the interviews were performed with spouses present, which may have limited the discourse of the participants, although they themselves chose this arrangement.

It is suggested that further studies are carried out with different methodological approaches, as

\section{REFERENCES}

1. Dawalibi NW, Goulart RMM, Prear LC. Fatores relacionados à qualidade de vida de idosos em programas para a terceira idade. Ciênc Saúde Colet [Internet]. 2014 [acesso em 03 dez. 2018];19(8):350512. Disponível em: http://www.scielo.br/scielo. php?pid=S1413-81232014000803505\&script $=$ sci_ abstract\&tlng=pt

2. Ribeiro DKMN, Lenardt MH, Michel T, Setocuchi LS, Grden CRB, Oliveira ES. Fatores contributivos para a independência funcional de idosos longevos. Rev Esc Enferm USP [Internet]. 2015 [acesso em 03 dez. 2018];49(1):89-95. Disponível em: http:// www.scielo.br/pdf/reeusp/v49n1/pt_0080-6234reeusp-49-01-0089.pdf the perception of care among elderly couples and its meaning needs to be explored more fully by scientific evidence. It is also important to investigate whether family composition and other sociodemographic characteristics influence the perceptions of care of the elderly couples.

\section{CONCLUSION}

Care among the elderly couples was considered to be a complex, multifaceted and transpersonal phenomenon, experienced, perceived and demonstrated by support with diseases and disabilities, as well as through housework. It was also manifested in the form of affection, friendship, warmth and companionship, with care being capable of promoting health and well-being in the life of the couple. All of these configurations of care indicate timely strategies for maintaining the overall functionality of the elderly, especially autonomy and independence.

It is important that health professionals consider elderly couples, rather than just individuals, when planning health actions and providing care to the elderly population. They should understand the multiple dimensions of care among elderly couples and their influence on health and well-being, so facilitating comprehensive, individualized and better quality care.

3. Mendes J, Soares VNM, Massi GAA. Percepções dos acadêmicos de Fonoaudiologia e Enfermagem sobre processos de envelhecimento e a formação para o cuidado aos idosos. Rev CEFAC [Internet]. 2015 [acesso em 03 dez. 2018];17(2):576-85. Disponível em: http://www.scielo.br/scielo.php?pid=S151618462015000200576\&script=sci_abstract\&tlng $=$ pt

4. Silva LA, Comin FS, Santos MA. Casamentos de longa duração: recursos pessoais como estratégias de manutenção do laço conjugal. Psico-USF [Internet]. 2017 [acesso em 03 dez. 2018];22(2):22335. Disponível em: http://www.scielo.br/scielo. php?pid=S1413-82712017000200323\&script $=$ sci_ abstract\&tlng $=\mathrm{pt}$ 
5. Costa SRD, Castro EAB, Acioli S. Apoio de enfermagem ao autocuidado do cuidador familiar. Rev enferm UERJ [Internet]. 2015 [acesso em 03 dez. 2018];22(3):197-202. Disponível em: http://www. facenf.uerj.br/v23n2/v23n2a09.pdf

6. Bardin L. Análise de conteúdo. Lisboa: Edições 70, 2011.

7. Watson J. Caring as the essence and science of Nursing and health care. Mundo Saúde [Internet]. 2009 [acesso em 03 dez. 2018];33(2):143-9. Disponível em: http://www.saocamilo-sp.br/pdf/mundo_ saude/67/143a149.pdf

8. Brasil. Ministério da Saúde. Conselho Nacional de Saúde. Resolução 466/2012, de 12 de dezembro de 2012. Dispõe de Normas Técnicas envolvendo seres humanos. Diário Oficial da União. 13 de junho 2013; Seção 1:59.

9. Lima CFM, Trotte LAC, Souza TA, Ferreira AMO, Caldas CP. Sexualidade do cônjuge que cuida do idoso demenciado: revisão integrativa da literatura. Rev Min Enferm [Internet] 2015 [acesso em 03 dez. 2018];19(9):211-7. Disponível em: http://www.reme. org.br/artigo/detalhes/1016

10. Dantas DV, Batista Filho RC, Dantas RAN, Nascimento JCP, Nunes HMA, Rodriguez GCB, et al. Sexualidade e qualidade de vida na terceira idade. Rev Bras Pesqui Saúde [Internet]. 2017 [acesso em 03 dez. 2018];19(4):140-8. Disponível em: http://www.periodicos.ufes.br/RBPS/article/ viewFile/19814/13235

11. Andriolo BNG, Santos NV, Volse AA, Fé LCM, Amaral ARC, Carmo BMSS, et al. Avaliação do grau de funcionalidade em idosos usuários de um centro de saúde. Rev Soc Bras Clin Med [Internet]. 2016 [acesso em 03 dez. 2018];14(3):139-44. Disponível em: http:// docs.bvsalud.org/biblioref/2016/10/2125/139-144.pdf
12. Gonzalez LMB, Seidl EMF. Envelhecimento ativo e apoio social entre homens participantes de um Centro de Convivência para Idosos. Rev Kairós Gerontol [Internet]. 2014 [acesso em 03 dez. 2018];7(4):119-39. Disponível em: https://revistas.pucsp.br/index.php/ kairos/article/view/23650

13. Boas SV, Oliveira CS, Heras SL. Tarefas domésticas e gênero: representação de estudantes do ensino superior. Ex æquo [Internet]. 2014 [acesso em 03 dez. 2018];30:113-29. Disponível em: http://www.scielo. mec.pt/scielo.php?script $=$ sci_abstract\&pid $=$ S0874$55602014000200009 \& \operatorname{lng}=$ pt\&nrm=.pf

14. Queiroz DB, Araújo CM, Oliveira LC, Novais MM, Andrade L A, Reis LA. Funcionalidade, aptidão motora e condições de saúde em idosos longevos residentes em domicílio. Arq Ciênc Saúde [Internet]. 2016 [acesso em 03 dez. 2018];23(2):47-53. Disponível em: http://www.cienciasdasaude.famerp.br/index. $\mathrm{php/racs/article/view/281}$

15. Santos GLA, Santana R F, Broca PV. Capacidade de execução das atividades instrumentais de vida diária em idosos: Etnoenfermagem. Esc Anna Nery Enferm [Internet]. 2016 [acesso em 03 dez. 2018];20(3):1-

7. Disponível em: http://www.scielo.br/pdf/ean/ v20n3/1414-8145-ean-20-03-20160064.pdf

16. Farias RCP, Schimidit A. Dádiva e sociabilidade na velhice: o caso de dois casais de idosos camponeses. Rev Bras Econ Dome [Internet]. 2015 [acesso em 03 dez. 2018];26(1):123-42. Disponível em: https:// www2.cead.ufv.br/espacoProdutor/scripts/verArtigo. php?codigo $=64 \&$ acao $=$ exibir

17. Rabelo DF, Neri AL. A Complexidade emocional dos relacionamentos intergeracionais e a saúde mental dos idosos. Pensando Fam [Internet]. 2014 [acesso em 03 dez. 2018];18(1):138-53. Disponível em: http://pepsic. bvsalud.org/pdf/penf/v18n1/v18n1a12.pdf 